\title{
Pengaruh readiness dan self-confidence terhadap penguasaan geometri transformasi mahasiswa pendidikan matematika universitas Muhammadiyah Purworejo
}

\author{
Nila Kurniasih, Erni Puji Astuti, Puji Nugraheni ${ }^{1}$
}

\begin{abstract}
Abstrak: Penelitian kuantitatif ini bertujuan untuk mengetahui adanya pengaruh positif dan signifikan antara readiness, self-confidence, serta readiness dan self-confidence secara bersama-sama terhadap penguasaan mahasiswa pada mata kuliah Geometri Transformasi. Populasi penelitian adalah mahasiswa program studi pendidikan matematika yang mengambil mata kuliah Geometri Transformasi. Sampel diambil $25 \%$ dari populasi. Pengumpulan data menggunakan kuesioner untuk mengukur readiness dan self-confidence dan dokumentasi untuk memperoleh data penguasaan mahasiswa. Analisis data menggunakan analisis regresi dan analisis korelasi. Hasil penelitian menunjukkan bahwa terdapat pengaruh yang positif dan signifikan antara readiness, self-confidence, serta readiness dan selfconfidence secara bersama-sama terhadap penguasaan mahasiswa pada mata kuliah Geometri Transformasi.
\end{abstract}

Kata kunci: Readiness; Self-confidence; Penguasaan Mahasiswa; Geometri Transformasi

\begin{abstract}
This quantitative research aims to determine whether there is a positive and significant influence between: 1 ) readiness to learn and students' mastery 2) self-confidence and student's mastery, and 3) readiness to learn and self-confidence collectively together with students' mastery in Transformation Geometry course. The population of this research is students of Mathematics Education Program who took Transformation Geometry course. The Sample is taken 25\% of the population. The data collection uses questionnaires to measure the readiness to learn and self-confidence, and documentation methods to acquire data students' mastery of Transformation Geometry course. Data analysis employs regression analysis and correlation analysis. The results show that there is a positive and significant influence between: 1) student's readiness to learn with students' mastery, 2) selfconfidence with student's mastery, and 3) readiness to learn and selfconfidence collectively together with student's mastery of Transformation Geometry course.
\end{abstract}

\footnotetext{
1 Universitas Muhammadiyah Purworejo, 3rniee.ast84@gmail.com
} 
Keywords: Readiness; Self-confidence; Undergraduate Students' Mastery; Transformation Geometry

\section{A. Pendahuluan}

Belajar merupakan proses dari seorang individu yang berupaya mencapai tujuan belajar atau yang biasa disebut prestasi belajar. Oleh karena itu, untuk mendapatkan prestasi belajar yang baik dan maksimal diperlukan persiapan mahasiswa dalam belajar yang baik pula. Persiapan mahasiswa dalam belajar merupakan kebutuhan pokok yang harus dipenuhi oleh mahasiswa dalam mencapai tujuan belajar. Untuk mencapai tujuan tersebut maka setiap mahasiswa harus mempunyai kesiapan dalam belajar (readiness) dan rasa percaya diri (self-confidence) yang besar. Readiness dan self-confidence masing-masing individu sebagai seorang mahasiswa dalam belajar akan menentukan kualitas proses dan prestasi belajarnya.

Berdasarkan hasil pengamatan pada saat proses pembelajaran mata kuliah Geometri Transformasi mahasiswa semester VI Program Studi Pendidikan Matematika Universitas Muhammadiyah Purworejo dijumpai hal-hal, yaitu: hasrat mahasiswa dalam belajar masih kurang, hal ini terlihat pada saat proses pembelajaran mereka kurang berkonsentrasi dan sepertinya malas mengikuti kuliah; sebagian besar mahasiswa dalam suatu kelas yang tidak membawa buku sumber belajar ataupun modul padahal pada pertemuan sebelumnya sudah diingatkan untuk mempersiapkan; dan pada saat diberi pertanyaan mereka kurang cepat dalam merespon, cenderung diam dan menunggu penjelasan dosen. Keadaan seperti itu bersumber dari kesiapan (readiness) mahasiswa dalam mengikuti pembelajaran yang masih kurang. Sebagai seorang mahasiswa tidak dapat terlepas dari aktivitas belajar, dan untuk menunjang tersebut diperlukan kesiapan belajar (readiness).

Selain itu, menurut informasi dari beberapa mahasiswa ada yang merasa tertekan pada saat menghadapi masalah yang menghambat proses perkuliahan. Mereka merasa tidak nyaman berbicara dengan dosen, takut menemui dosen, kesulitan pada saat menyelesaikan tugas- 
tugas yang diberikan oleh dosen, khawatir mendapatkan nilai rendah, dan kurang mandiri dalam mengerjakan tugas yang diberikan dosen. Keadaan seperti itu bersumber dari perasaan kurang percaya diri (self-confidence) dari mahasiswa.

Penelitian Tisngati \& Meifiani (2014) menjelaskan bahwa tidak terdapat pengaruh secara bersamaan kepercayaan diri dan pola asuh orang tua terhadap prestasi belajar matematika. Di sisi lain, terdapat pengaruh kepercayaan diri pada mata kuliah Teori Bilangan terhadap prestasi belajar matematika. Sementara itu, penelitian Saifullah (2013) menunjukkan bahwa ada pengaruh yang positif antara kesiapan belajar terhadap hasil belajar matematika pokok bahasan Limit pada Peserta Didik Kelas XI Semester 2 di Madrasah Aliyah Matholi'ul Huda Bugel Jepara Tahun Pelajaran 2012/ 2013.

Menurut Djamarah dalam Fatchurrachman (2011) kesiapan belajar jangan hanya diterjemahkan siap dalam arti fisik, tetapi juga diartikan dalam arti psikis dan materil. Kesiapan fisik misalnya kondisi badan yang sehat dan bugar. Kesiapan psikis misalnya ada hasrat untuk belajar, dapat berkonsentrasi, dan ada motivasi instrinsik. Kesiapan materil misalnya ada bahan yang dipelajari atau dikerjakan berupa buku pelajaran, catatan pelajaran, dan modul. Pendapat lain dikemukakan Slameto (2010) bahwa kesiapan adalah keseluruhan semua kondisi individu yang membuatnya siap untuk memberikan respon atau jawaban di dalam cara tertentu terhadap situasi tertentu. Kondisi tertentu yang dimaksud adalah kondisi fisik dan psikisnya, sehingga untuk mencapai tingkat kesiapan yang maksimal diperlukan kondisi fisik dan psikis yang saling menunjang kesiapan individu dalam proses pembelajaran.

Ada beberapa faktor yang dapat mempengaruhi kesiapan belajar siswa. Djamarah (2002) merangkum beberapa bentuk kesiapan dalam belajar, yaitu:

a. Kesiapan fisik. Misalnya tubuh tidak sakit (jauh dari gangguan lesu, mengantuk, dan sebagainya).

b. Kesiapan psikis. Misalnya ada hasrat untuk belajar, dapat berkonsentrasi, dan ada motivasi instrinsik.

c. Kesiapan materil. Misalnya ada bahan yang dipelajari atau dikerjakan berupa buku bacaan, dan catatan. 
Berdasarkan beberapa pendapat di atas, dalam penelitian ini yang digunakan sebagai dasar indikator kesiapan belajar (Readiness) sebagai berikut.

a. Kondisi fisik mahasiswa, misalnya pendengaran, penglihatan, dan kesehatan.

b. Kondisi mental mahasiswa, misalnya penyesuaian diri.

c. Kondisi emosional mahasiswa, misalnya kondisi konflik dan tegang.

d. Kebutuhan misalnya buku pelajaran, catatan pelajaran, dan perlengkapan.

e. Pengetahuan, misalnya membaca buku pelajaran.

Fatimah (2006) mengemukakan bahwa kepercayaan diri adalah sikap positif seorang individu yang memampukan dirinya untuk mengembangkan penilaian positif, baik terhadap diri sendiri maupun terhadap lingkungan atau situasi yang dihadapinya. Hal ini bukan berarti bahwa individu tersebut mampu dan kompeten melakukan segala sesuatunya seorang diri. Rasa percaya diri sebenarnya merujuk pada adanya beberapa aspek dari kehidupan individu bahwa ia merasa memiliki kompetensi, yakin mampu dan percaya bahwa ia bisa karena didukung oleh pengalaman, potensi aktual, prestasi serta harapan yang realistik terhadap diri sendiri. Pendapat lain dikemukakan oleh Ghufron dan Rini (2011) adalah keyakinan untuk melakukan sesutau pada diri subjek sebagai karakteristik pribadi yang di dalamnya terdapat kemampun diri, optimis, objektif, bertanggung jawab, rasional, dan realistis. Rasa percaya diri yang besar dalam diri individu, mengakibatkan mereka merasa yakin akan kemampuannya sendiri dan tidak bergantung kepada orang lain.

Lauster (1990) mengemukakan aspek-aspek yang terkandung dalam kepercayaan diri antara lain:

a. Ambisi. Ambisi merupakan dorongan untuk mencapai hasil yang diperlihatkan kepada orang lain. Orang yang percaya diri cenderung memiliki ambisi yang tinggi. Mereka selalu berpikiran positif dan berkeyakinan bahwa mereka mampu untuk melakukan sesuatu. 
b. Mandiri. Individu yang mandiri adalah individu yang tidak tergantung pada individu lain karena mereka merasa mampu untuk menyelesaikan segala tugasnya dengan baik.

c. Optimis. Individu yang optimis akan selalu berpikiran positif, selalu beranggapan bahwa akan berhasil, yakin dan dapat menggunakan kemampuan dan kekuatannya secara efektif.

d. Tidak mementingkan diri sendiri. Sikap percaya diri tidak hanya mementingkan kebutuhan pribadi akan tetapi selalu peduli kepada orang lain.

e. Toleransi. Sikap toleransi selalu mau menerima pendapat dan perilaku orang lain yang berbeda dengan dirinya.

Berdasarkan beberapa pendapat di atas maka indikator self-confidence dalam penelitian ini meliputi beberapa aspek sebagai berikut.
a. Mandiri
b. Optimis
c. Toleransi
d. Bertanggung jawab
e. Mampu menyelesaikan masalah

Penelitian ini bertujuan untuk mengetahui adanya pengaruh yang positif dan signifikan antara readiness, self-confidence, serta readiness dan self-confidence secara bersama-sama terhadap penguasaan mahasiswa pada mata kuliah Geometri Transformasi.

\section{B. Metode Penelitian}

Dalam penelitian ini, peneliti menggunakan metode penelitian kuantitatif (asosiatif), karena peneliti akan meninjau apakah ada pengaruh antar variabel yang digunakan yaitu mencari pengaruh antara variabel bebas dengan variabel terikat. Variabel bebas dalam penelitian ini yaitu kesiapan belajar (readiness) dan kepercayaan diri (self-confidence) sedangkan variabel terikatnya adalah penguasaan mahasiswa. Paradigma dari penelitian ini tergambar dalam bagan berikut. 


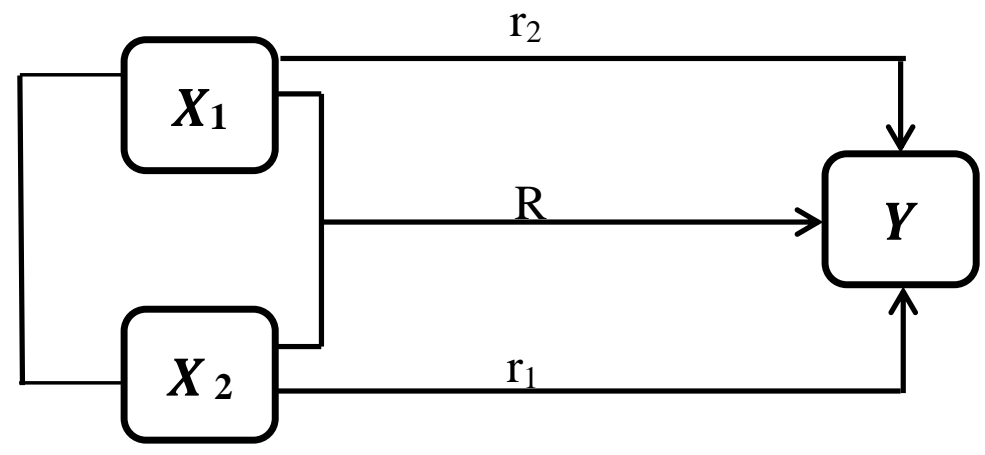

Gambar 1. Paradigma penelitian

Keterangan:

$\mathrm{X}_{1}=$ readiness (variabel independen)

$\mathrm{X}_{2}=$ self-confidence (variabel independen)

$\mathrm{Y}=$ penguasaan mahasiswa (variabel dependen)

Populasi penelitian ini adalah mahasiswa Program Studi Pendidikan Matematika yang menempuh mata kuliah Geometri Transformasi. Untuk menentukan besarnya sampel apabila subjek kurang dari 100, lebih baik diambil semua sehingga penelitiannya penelitian populasi. Jika subjeknya lebih besar dapat diambil antara 20-25 \% (Arikunto, 2002). Rumus yang digunakan untuk pengambilan sampel adalah :

$$
\mathrm{n}=25 \% \times \mathrm{N}, \quad \mathrm{n}=\text { besar sampel, } \mathrm{N}=\text { besar populasi }
$$

Jadi, dalam penelitian ini sampel diambil $25 \%$ dari populasi yaitu sebanyak 50 mahasiswa.

Menurut Sugiyono (2013) variabel penelitian adalah segala sesuatu yang ditetapkan oleh peneliti untuk dipelajari sehingga diperoleh informasi tentang hal tersebut, kemudian ditarik kesimpulan. Pada penelitian ini melibatkan dua variabel, yaitu variabel bebas dan variabel terikat.

\section{Variabel Bebas}

a. Kesiapan belajar (readiness)

Kesiapan belajar (readiness) adalah keseluruhan semua kondisi individu yang membuatnya siap untuk memberikan respon atau jawaban di dalam cara tertentu terhadap situasi tertentu. Kondisi 
tertentu yang dimaksud adalah kondisi fisik dan psikisnya, sehingga untuk mencapai tingkat kesiapan yang maksimal diperlukan kondisi fisik dan psikis yang saling menunjang kesiapan individu dalam proses pembelajaran.

b. Kepercayaan diri (self-confidence)

Kepercayaan diri (self-confidence) adalah kondisi mental seseorang yang memberi keyakinan kuat pada kemampuan dirinya. Untuk melakukan tindakan dalam mencapai tujuan dalam hidupnya. Percaya diri adalah sikap percaya dan yankin akan kemampuan yang dimilki oleh seseorang. Dapat memandang dirinya secara positif sehingga mampu bersosialisasi secara baik dengan orang lain.

Variabel Terikat

Variabel terikat pada penelitian ini adalah penguasaan mahasiswa. Penguasaan mahasiswa yang dimaksud adalah prestasi belajar mahasiswa setelah menempuh mata kuliah Geometri Transformasi.

Adapun teknik pengumpulan data dalam penelitian ini, yaitu:

1. Angket

Menurut Sugiyono (2013), angket merupakan teknik pengumpulan data yang dilakukan dengan cara memberikan seperangkat pertanyaan atau pernyataan secara tertulis kepada responden untuk dijawab sesuai dengan situasi maupun kondisi yang ada. Penggunaan angket dalam teknik pengumpulan data merupakan suatu langkah yang efisien untuk mengukur variabel yang digunakan dalam penelitian. Angket dalam penelitian ini digunakan untuk mengukur kesiapan belajar (readiness) dan kepercayaan diri (selfconfidence).

\section{Dokumentasi}

Dalam penelitian ini dokumentasi digunakan untuk mendapatkan data tentang daftar nama, jumlah siswa yang menjadi populasi serta untuk penentuan sampel, nilai ujian akhir semester (UAS) mata kuliah Geometri Transformasi. Metode dokumentasi dalam penelitian ini digunakan untuk mengetahui data penguasaan Geometri Transformasi. 
Menurut Arikunto (2006), angket atau kuesioner merupakan sejumlah pertanyaan tertulis yang digunakan peneliti untuk memperoleh informasi dari responden. Dalam hal ini menyangkut laporan tentang pribadinya. Dalam penelitian ini jenis angket yang digunakan dilihat dari sudut pandang cara menjawabnya adalah kuesioner tertutup, yang berarti responden sudah disediakan jawabannya, sehingga responden tinggal memilih. Dilihat dari jawaban yang diberikan merupakan kuesioner langsung, yaitu responden menjawab tentang dirinya. Dipandang dari bentuknya, jenis kuesioner ini merupakan kuesioner pilihan ganda.

Analisis data menggunakan analisis regresi dan analisis korelasi, dengan uji prasyarat yaitu uji normalitas, uji linearitas, uji keberartian regresi linear sederhana, uji keberartian koefisien regresi linear sederhana, uji independensi, uji keberartian regresi linear ganda, dan uji keberartian koefisien regresi linear ganda.

\section{Temuan dan Pembahasan}

Penelitian dilakukan dengan memberikan instrumen berupa angket readiness dan self-confidence pada mata kuliah geometri transformasi. Angket readiness diperoleh jumlah 2003 dengan rata-rata 41,729, untuk angket self-confidence diperoleh jumlah 1925 dengan rata-rata 40,104 dan penguasaan Geometri Transformasi diperoleh jumlah 3159 dengan rata-rata 65,813 .

Dalam penelitian ini, peneliti melakukan dua tahap analisis yaitu analisis korelasi linear dan analisis regresi. Analisis korelasi linear terdiri dari uji normalitas, uji koefisien korelasi linear dan uji signifikansi. Untuk menguji normalitas data menggunakan metode Liliefors. Hasil perhitungan uji normalitas data readiness, self-confidence dan penguasaan geometri transformasi diperoleh populasi berdistribusi normal.

Uji selanjutnya adalah uji koefisien korelasi. Dari perhitungan koefisien korelasi diperoleh koefisien korelasi antara $X_{1}$ dan $Y$ sebesar 0,462 dan termasuk pada kategori sedang. Jadi, terdapat hubungan yang sedang antara $X_{1}$ dan $Y$. Uji signifikansi koefisien korelasi antara $X_{1}$ dan $Y$ diperoleh nilai $t_{o b s}=3,530$ dan $t_{\text {tabel }}=2,021$ dengan $D K=$ $\{t \mid t>2,021\}$. Maka $t_{o b s} \in D K$, sehingga $H_{0}$ ditolak. Maka ada hubungan yang positif dan signifikan antara $X_{1}$ dan $Y$. Dengan demikian terdapat 
hubungan yang positif dan signifikan antara readiness dengan penguasaan mahasiswa pada mata kuliah Geometri Transformasi.

Tahap selanjutnya yaitu tahap analisis regresi. Sebelum menentukan persamaan regresi, terlebih dahulu melakukan uji prasyarat yaitu uji linearitas regresi dan uji keberartian regresi. Dari hasil perhitungan uji linearitas antara $X_{1}$ dan $Y$ diperoleh nilai $F_{o b s}=1,090$ dan $F_{\text {tabel }}=$ 2,090 dengan $D K=\{F \mid F>2,090\}$. Karena $F_{o b s} \notin D K$, maka $H_{0}$ diterima, berarti hubungan antara $X_{1}$ dan $Y$ linear. Selanjutnya yaitu uji keberartian, dari hasil perhitungan uji keberartian $X_{1}$ dan $Y$ diperoleh niali $F_{\text {obs }}=12,458$ dan $F_{\text {tabel }}=4,080$ dengan $D K=\{F \mid F>4,080\}$. Karena $F_{\text {obs }} \in D K$ maka $H_{0}$ ditolak. Sehingga hubungan linear antara $X_{1}$ dan $Y$ berarti. Selanjutnya, peneliti melakukan analisis regresi sederhana dan regresi ganda. Berdasarkan perhitungan data yang dilakukan dalam penelitian ini diperoleh persamaan regresi linear sederhana antara $X_{1}$ dan $Y$ yaitu $\hat{Y}=1,104+1,551 X_{1}$.

Dari hasil analisis data di atas maka dapat dikatakan bahwa terdapat pengaruh yang positif dan signifikan antara readiness dengan penguasaan mahasiswa pada mata kuliah geometri transformasi. Artinya semakin baik tingkat kesiapan belajar mahasiswa dalam mengikuti perkuliahan geometri transformasi, maka akan semakin baik pula penguasaan mahasiswa pada mata kuliah tersebut sehingga hasil yang dicapai dapat maksimal. Agar mahasiswa dapat mencapai penguasaan yang baik maka yang perlu diperhatikan adalah mahasiswa harus dapat mempersiapkan kondisi fisiknya terutama kondisi kesehatannya. Dengan kondisi fisik yang sehat maka materi yang disampaikan dosen dapat diserap dengan baik. Selain itu, mahasiswa harus mempersiapkan kondisi mentalnya, dapat menyesuaikan diri dengan lingkungan belajarnya. Dengan demikian maka mahasiswa akan merasa nyaman dalam mengikuti kegiatan perkuliahan.

Faktor yang lain adalah dapat mengontrol emosinya, misalnya tidak tegang ketika mengikuti perkuliahan. Selain itu, kebutuhan mahasiswa juga harus terpenuhi misalnya buku pegangan kuliah mereka harus punya. Meskipun buku bukan satu-satunya sumber belajar tetapi setiap mahasiswa diwajibkan memiliki buku pegangan agar belajarnya lebih mudah dan terarah. Buku catatan juga diperlukan untuk mencatat hal-hal yang belum ada di buku pegangan, sehingga bisa untuk saling melengkapi. Kesiapan mahasiswa juga bisa dilihat dari lengkap tidaknya alat tulis yang 
mereka bawa. Kalau ada mahasiswa yang meminjam bopoint atau pensil dengan alasan ketinggalan atau lupa, itu menandakan bahwa mahasiswa tersebut belum siap mengikuti kegiatan perkuliahan. Dan faktor pengetahuan yaitu mahasiswa yang siap mengikuti kegiatan perkuliahan berarti paling tidak dia sudah membaca materi yang akan disampaikan oleh dosen agar mereka mengetahui gambarannya.

Koefisien korelasi antara $X_{2}$ dan $Y$ sebesar 0,464 dan termasuk pada kategori sedang. Uji signifikansi koefisien korelasi antara $X_{2}$ dan $Y$ diperoleh nilai $t_{o b s}=3556$ dan $t_{\text {tabel }}=2,021$ dengan $D K=$ $\{t \mid t>2,021\}$. Maka $t_{o b s} \in D K$, sehingga $H_{0}$ ditolak. Maka ada hubungan yang positif dan signifikan antara $X_{2}$ dan $Y$. Dengan demikian terdapat hubungan yang positif dan signifikan antara self-confidence dengan penguasaan mahasiswa pada mata kuliah geometri transformasi.

Tahap selanjutnya yaitu tahap analisis regresi. Sebelum menentukan persamaan regresi, terlebih dahulu melakukan uji prasyarat. Uji prasyaratnya yaitu uji linearitas regresi dan uji keberartian regresi. Uji linearitas $X_{2}$ dan $Y$ diperoleh $F_{o b s}=1,471$ dan $F_{\text {tabel }}=2,010$ dengan $D K=\{F \mid F>2,010\}$. Karena $F_{o b s} \notin D K$, maka $H_{0}$ diterima, berarti hubungan antara $X_{2}$ dan $Y$ linear. Selanjutnya yaitu Uji keberartian. Dari Uji keberartian $X_{2}$ dan $Y$ diperoleh nilai $F_{o b s}=12,648$ dan $F_{\text {tabel }}=$ 4,080 dengan $D K=\{F \mid F>4,080\}$. Karena $F_{o b s} \in D K$ maka $H_{0}$ ditolak sehingga hubungan linear antara $X_{2}$ dan $Y$ berarti.

Selanjutnya peneliti melakukan analisis regresi sederhana dan regresi ganda. Berdasarkan perhitungan data yang dilakukan dalam penelitian ini diperoleh persamaan regresi linear sederhana antara $X_{2}$ dan $Y$, persamaan regresi linear sederhana antara $X_{2}$ dan $Y$ yaitu $\hat{Y}=$ $12,197+1,337 X_{2}$.

Dari hasil analisis data di atas maka dapat dikatakan bahwa terdapat pengaruh yang positif dan signifikan antara self-confidnce dengan penguasaan mahasiswa pada mata kuliah Geometri Transformasi. Artinya semakin baik tingkat kepercayaan diri mahasiswa dalam mengikuti perkuliahan geometri transformasi, maka akan semakin baik pula penguasaan mahasiswa pada mata kuliah tersebut sehingga hasil yang dicapai dapat maksimal. Agar mahasiswa dapat mencapai penguasaan yang baik maka yang perlu diperhatikan adalah mahasiswa harus mandiri artinya tidak tergantung pada orang lain karena mereka merasa mampu 
untuk menyelesaikan segala tugasnya dengan baik. Optimis, artinya mahasiswa akan selalu berpikiran positif, selalu beranggapan bahwa akan berhasil, yakin dan dapat menggunakan kemampuan dan kekuatannya secara efektif. Selain itu faktor yang lain adalah memiliki sikap toleran terhadap orang ain, maksudnya adalah selalu mau menerima pendapat dan perilaku orang lain yang berbeda dengan dirinya. Mau bertanggung jawab terhadap keputusan dan tindakannya serta mampu menyelsaikan masalah.

Koefisien korelasi ganda antara $X_{1}$ dan $X_{2}$ dengan $Y$ sebesar 0,507 termasuk pada kategori sedang. Uji signifikansi koefisien korelasi ganda diperoleh $F_{\text {obs }}=7,796$ dan $F_{\text {tabel }}=3,320$ dengan $D K=\{F|F\rangle$ $3,320\}$. Maka $F_{\text {obs }} \in D K$, sehingga $H_{0}$ ditolak. Maka ada hubungan yang positif dan signifikan antara $X_{1}$ dan $X_{2}$ dengan $Y$. Dengan demikian terdapat hubungan yang positif dan signifikan antara readiness dan self confidence secara bersama-sama dengan penguasaan mahasiswa pada mata kuliah Geometri Transformasi.

Tahap selanjutnya adalah Uji keberartian ganda antara $X_{1}$ dan $X_{2}$ dengan $Y$ diperoleh nilai $F_{\text {obs }}=5,623$ dan $F_{\text {tabel }}=3,230$ dengan $D K=$ $\{F \mid F>3,230\}$. Karena $F_{o b s} \in D K$ maka $H_{0}$ ditolak. Sehingga hubungan antara $X_{1}$ dan $X_{2}$ dengan $Y$ berarti. Selanjutnya peneliti melakukan analisis regresi sederhana dan regresi ganda. Berdasarkan perhitungan data yang dilakukan dalam penelitian ini diperoleh persamaan regresi linear sederhana antara $X_{1}$ dan $X_{2}$ dengan $Y$, persamaan regresi linear ganda yaitu $\hat{Y}=9,151+0,920 X_{1}+0,456 X_{2}$.

Berdasarkan hasil analisis data di atas maka dapat dikatakan bahwa terdapat pengaruh yang positif dan signifikan antara readiness dan selfconfidnce secara bersama-sama dengan penguasaan mahasiswa pada mata kuliah Geometri Transformasi. Artinya semakin baik tingkat kesiapan belajar dan kepercayaan diri mahasiswa dalam mengikuti perkuliahan Geometri transformasi, maka akan semakin baik pula penguasaan mahasiswa pada mata kuliah tersebut sehingga hasil yang dicapai dapat maksimal. Agar mahasiswa dapat mencapai penguasaan yang baik maka yang perlu diperhatikan adalah mahasiswa harus dapat mempersiapkan kondisi fisiknya terutama kondisi kesehatannya. Dengan kondisi fisik yang sehat maka materi yang disampaikan dosen dapat diserap dengan baik. Selain itu, mahasiswa harus mempersiapkan kondisi mentalnya, dapat 
menyesuaikan diri dengan lingkungan belajarnya. Dengan demikian maka mahasiswa akan merasa nyaman dalam mengikuti kegiatan perkuliahan.

Faktor yang lain adalah dapat mengontrol emosinya, misalnya tidak tegang ketika mengikuti perkuliahan. Selain itu, kebutuhan mahasiswa juga harus terpenuhi misalnya buku pegangan kuliah mereka harus punya. Meskipun buku bukan satu-satunya sumber belajar tetapi setiap mahasiswa diwajibkan memiliki buku pegangan agar belajarnya lebih mudah dan terarah. Buku catatan juga diperlukan untuk mencatat hal-hal yang belum ada di buku pegangan, sehingga bisa untuk saling melengkapi. Kesiapan mahasiswa juga bisa dilihat dari lengkap tidaknya alat tulis yang mereka bawa. Kalau ada mahasiswa yang meminjam bopoint atau pensil dengan alasan ketinggalan atau lupa, itu menandakan bahwa mahasiswa tersebut belum siap mengikuti kegiatan perkuliahan. Dan faktor pengetahuan yaitu mahasiswa yang siap mengikuti kegiatan perkuliahan berarti paling tidak dia sudah membaca materi yang akan disampaikan oleh dosen agar mereka mengetahui gambarannya.

Selain itu mahasiswa harus mandiri artinya tidak tergantung pada orang lain karena mereka merasa mampu untuk menyelesaikan segala tugasnya dengan baik. Optimis, artinya mahasiswa akan selalu berpikiran positif, selalu beranggapan bahwa akan berhasil, yakin dan dapat menggunakan kemampuan dan kekuatannya secara efektif. Selain itu faktor yang lain adalah memiliki sikap toleran terhadap orang ain, maksudnya adalah selalu mau menerima pendapat dan perilaku orang lain yang berbeda dengan dirinya. Mau bertanggung jawab terhadap keputusan dan tindakannya serta mampu menyelsaikan masalah.

Dari hasil pembahasan tersebut maka dapat disimpulkan bahwa readiness berpengaruh pada penguasaan mahasiswa, self-confidence juga berpengaruh terhadap pengusaan mahasiswa, dan kedua-duanya juga berpengaruh. Oleh sebab itu, mahasiswa perlu memperhatikan faktorfaktor tersebut agar dapat mencapai penguasaan yang baik.

\section{Simpulan}

Berdasarkan hasil penelitian dan pembahasan, maka dapat disimpulkan bahwa. 
1. Terdapat pengaruh yang positif dan signifikan antara readiness dengan penguasaan mahasiswa pada mata kuliah geometri transformasi.

2. Terdapat pengaruh yang positif dan signifikan antara self-confidence dengan penguasaan mahasiswa pada mata kuliah geometri transformasi.

3. Terdapat pengaruh yang positif dan signifikan antara readiness dan self-confidence secara bersama-sama dengan penguasaan mahasiswa pada mata kuliah Geometri Transformasi.

Dari simpulan yang diperoleh dalam penelitian ini, maka peneliti menyampaikan saran-saran sebagai berikut.

1. Sebelum mengikuti kegiatan perkuliahan sebaiknya mahasiswa sudah membaca materi yang akan disampaikan oleh dosen agar mendapatkan gambaran tentang materi tersebut sehingga mahasiswa lebih siap dan dapat mengikuti kegiatan perkulihan dengan baik.

2. Kepercayaan diri perlu dibangun sejak dini, dimulai sejak mahasiswa semester I atau bahkan mungkin sebelum mereka masuk kuliah. Rasa percaya diri dapat dilatih dengan mereka mau mengungkapkan pendapat, menjawab pertanyaan yang diberikan oleh dosen tanpa ada rasa takut jika jawaban yang mereka sampaikan salah. Selain itu ketika mereka mengerjakan soal ujian, mereka harus yakin bahwa jawaban yang mereka tuliskan benar, sehingga tidak ada keinginan untuk mencontek pekerjaan teman. Dari situlah kepercayaan diri mahasiswa dapat terbangun.

3. Bagi dosen pengampu mata kuliah geometri transformasi perlu memperhatikan kesiapan belajar dan kepercayaan diri mahasiswa.

\section{Daftar Pustaka}

Arikunto, S. (2002). Prosedur penelitian suatu pendekatan praktik. Jakarta, Indonesia: Rineka Cipta.

Arikunto, S. (2006). Prosedur penelitian suatu pendekatan praktik (Edisi Revisi VI). Jakarta, Indonesia: Rineka Cipta. 
Djamarah, S.B. (2002). Rahasia Sukses Belajar. Jakarta, Indonesia: Rineka Cipta.

Fatchurrochman, R. (2011). Pengaruh motivasi berprestasi terhadap kesiapan belajar, pelaksanaan prakerin dan pencapaian kompetensi mata pelajaran produktif teknik kendaraan ringan kelas XI. Jurnal Pendidikan Teknologi Kejuruan, VII(2). $\quad n p$. Diakses di http://jurnal. upi.edu/invotec/view/657/pengaruh-motivasi-berprestasi-terhadap kesiapan-belajar,-pelaksanaan-prakerindan-pencapaian-kompetensi-matapelajaran-produktif.html

Fatimah, E. (2006). Psikologi perkembangan (perkembangan peserta didik). Bandung, Indonesia: Pustaka Setia.

Lauster, P. (1990). Personality test Alih Bahasa D. H. Gulo. Jakarta: Bumi Aksara.

Ghufron, N \& Rini, R. S. (2011). Teori-teori psikologi. Jogjakarta, Indonesia: ArRuzz Media.

Saifullah, M.A. (2013). Pengaruh kesiapan belajar terhadap hasil belajar matematika pokok bahasan limit pada peserta didik kelas XI semester 2 di Madrasah Aliyah Matholi'ul Huda Bugel Jepara tahun pelajaran 2012/2013 (Skripsi). Diakses di http://eprints.walisongo. ac.id/1648/1/063511009_Coverdll.pdf

Slameto. (2010). Belajar dan faktor-faktor yang mempengaruhinya. Jakarta, Indonesia: Rineka Cipta.

Sugiyono. (2013). Metode penelitian pendidikan (Pendekatan kuantitatif, kualitatif dan R\&D). Bandung, Indonesia: Alfabeta.

Tisngati, U \& Meifiani, N.I. (2014). Pengaruh kepercayaan diri dan pola asuh orang tua pada mata kuliah teori bilangan terhadap prestasi belajar. Jurnal $\begin{array}{lllll}\text { Derivat, } & 1 & \text { (2), } & \text { 8-18. }\end{array}$ http://upy.ac.id/ojs/index.php/mtk/article/view/77

Wulandari, R. (2012). Korelasi persepsi mata pelajaran matematika siswa kelas VI SD negeri se-Kecamatan Gamping tahun ajaran 2010/ 2011 (Skripsi). Yogyakarta. Diakses di http://eprints.uny.ac.id/8060/1/cover\%20-\%2008108247074.pdf 